\title{
RANCANG BANGUN APLIKASI BERBASIS WEB PERIZINAN PRAKTIK TENAGA KESEHATAN MENGGUNAKAN FRAMEWORK CODEIGNITER PADA DINAS KESEHATAN KOTA METRO
}

\author{
Erliyan Redy Susanto ${ }^{1)}$, Ferdy Ramadhan ${ }^{2)}$ \\ ${ }^{1)}$ Sistem Informasi, Universitas Teknokrat Indonesia \\ ${ }^{2)}$ Informatika, Universitas Teknokrat Indonesia \\ Jl. H.ZA Pagaralam, No 9-11, Labuhanratu,Bandarlampung \\ Email : erliyan.redy@teknokrat.ac.id ${ }^{1)}$,ferdyramadhan99@ gmail.com ${ }^{21}$
}

\begin{abstract}
Abstrak
Berbagai permasalahan Sumber Daya Manusia (SDM) kesehatan dijumpai di daerah-daerah di era desentralisasi, seperti masih rendahnya mutu tenaga kesehatan dan kesesuaian antara kompetensi dengan tuntutan pekerjaannya, juga kurangnya jumlah SDM kesehatan di daerah pedesaan. Tenaga kesehatan wajib memiliki izin dari pemerintah maupun lembaga kesehatan. Tujuan adanya perizinan praktik tenaga kesehatan untuk memenuhi kualitas dan menyamaratakan standar tenaga kesehatan di seluruh Oleh karena itu, diperlukan sebuah sistem yang dapat mempermudah tenaga kesehatan dalam memproses perizinan praktik tenaga kesehatan. Salah satunya membuat aplikasi berbasis web untuk perizinan praktik tenaga kesehatan yang bertujuan dapat meningkatkan kinerja Dinas Kesehatan Kota Metro dalam melayani perizinan praktik tenaga kesehatan. Metode pengembangan sistem yang digunakan adalah metode extreme programming menurut Pressman (2002). Perancangan aplikasi dibuat berdasarkan Use Case Diagram, Activity Diagram, dan Class Diagram. Sedangkan Framework yang digunakan dalam pembuatan aplikasi web ini adalah Codeigniter. Metode pengujian yang digunakan adalah Blackbox Testing. Hasil pengujian admin oleh 4 (empat) orang staff perizinan menunjukan bahwa aplikasi dapat melakukan semua fungsinya dengan benar sehingga kualitas perangkat lunak $100 \%$ valid. Hasil pengujian sekretariat oleh 2 (dua) orang sekretariat menunjukan bahwa aplikasi dapat melakukan semua fungsinya dengan benar sehingga kualitas perangkat lunak 100\% valid. Hasil pengujian pemohon atau tenaga kesehatan yang diwakili oleh 4 (empat) orang staff perizinan menunjukan bahwa aplikasi dapat melakukan semua fungsinya dengan benar sehingga kualitas perangkat lunak $100 \%$ valid. Berdasarkan hasil dari beberapa pengujian yang telah dilakukan menunjukan bahwa aplikasi layak digunakan oleh Dinas Kesehatan Kota Metro untuk meningkatkan kinerja dalam memproses perizinan praktik tenaga kesehatan.
\end{abstract}

Kata Kunci : Perizinan Praktik Tenaga Kesehatan, Kota Metro, Extreme Programming, Codeigniter

\section{Pendahuluan}

\section{A. Latar Belakang}

Berbagai permasalahan Sumber Daya Manusia (SDM) kesehatan dijumpai di daerah-daerah di era desentralisasi, seperti masih rendahnya mutu tenaga kesehatan dan kesesuaian antara kompetensi dengan tuntutan pekerjaannya, juga kurangnya jumlah SDM kesehatan di daerah pedesaan. Gambaran tersebut dijumpai pula di Provinsi Lampung. Sejak desentralisasi diterapkan di Indonesia, kabupaten memiliki fleksibilitas untuk mengatur aspek-aspek pemerintahan yang mencakup beberapa sektor, termasuk sektor kesehatan (Misnaniarti, 2010). Sehubungan dengan pelaksanaan desentralisasi kesehatan maka terdapat kecenderungan perubahan rumah sakit dan puskesmas ke arah lembaga usaha, sedangkan dinas kesehatan menjadi lembaga birokrat yang harus memahami good governance(Sopacua dan Budijanto, 2007).

Tenaga kesehatan mempunyai kewenangan untuk menyelenggarakan pelayanan kesehatan dan dalam menyelenggarakan pelayanan kesehatan tenaga kesehatan wajib memiliki izin dari pemerintah maupun lembaga kesehatan. Sebagai lembaga kesehatan, Dinas Kesehatan Kota Metro mempunyai tugas salah satunya untuk melayani perizinan praktik tenaga kesehatan. Tujuan adanya perizinan praktik tenaga kesehatan untuk memenuhi kualitas dan menyamaratakan standar tenaga kesehatan di seluruh Indonesia.

Pada Dinas Kesehatan Kota Metro, pelayanan perizinan praktik tenaga kesehatan sudah terkomputerisasi akan tetapi masih menggunakan microsoft excel dan microsoft word sehingga pemrosesan data yang diperlukan oleh seksi perizinan Dinas Kesehatan Kota Metro membutuhkan waktu yang lama, dan bagi pemohon yang akan mengurus perizinan praktek atau kerja juga membutuhkan waktu dua hari dan biaya transportasi untuk membuat perizinan praktik tenaga kesehatan.

Masalah-masalah tersebut di atas disebabkan sistem perizinan yang belum tersusun, sehingga mengharuskan pihak Dinas Kesehatan untuk menerapkan sistem perizinan yang mampu memproses data perizinan secara 
cepat dan mampu menyimpan serta menampilkan datadata yang berkaitan dengan sistem perizinan praktik tenaga kesehatan sehingga informasi yang dihasilkan lebih cepat, dan dapat terkelola dengan baik.

Berdasarkan penjelasan diatas, maka menjadi suatu pertimbangan bagi penulis untuk membuat "Rancang Bangun Aplikasi Berbasis Web Perizinan Praktik Tenaga Kesehatan Menggunakan Framework Codeigniter Pada Dinas Kesehatan Kota Metro" upaya ini dilakukan untuk mempermudah tenaga kesehatan maupun Dinas Kesehatan Metro dalam memproses perizinan praktik tenaga kesehatan.

\section{B. Tinjauan Pustaka}

\section{Perizinan Tenaga Kesehatan}

Tenaga kesehatan seperti dokter, bidan, perawat, dan tenaga kesehatan lain diharuskan memiliki izin praktik. Sejak tahun 2011, semua tenaga kesehatan terutama tenaga strategis seperti bidan perawat harus memiliki Surat Tanda Registrasi (STR) dan izin praktik. Ini dilakukan untuk memenuhi kualitas dan menyamaratakan standar tenaga kesehatan di seluruh Indonesia. Selain meningkatkan mutu pelayanan kesehatan yang diberikan tenaga kesehatan, perizinan tenaga kesehatan dapat melindungi masyarakat atas tindakan yang dilakukan tenaga kesehatan, juga memberikan kepastian hukum bagi masyarakat yang dilayani dan tenaga kesehatan itu sendiri.

\section{Konsep Dasar Rancang Bangun}

Rancang merupakan serangkaian prosedur untuk menerjemahkan hasil analisa dan sebuah sistem ke dalam bahasa pemrograman untuk mendeskripsikan dengan detail bagaimana komponen-komponen sistem diimplementasikan. Sedangkan pengertian Bangun atau pembangunan sistem adalah kegiatan menciptakan sistem baru maupun mengganti atau memperbaiki sistem yang telah ada baik secara keseluruhan maupun sebagian (Hidayah, Utami dan Suhendar, 2015).

\section{Codeigniter}

CodeIgniter adalah sebuah framework yang digunakan untuk membuat sebuah aplikasi berbasis web yang disusun dengan menggunakan bahasa PHP (Yudhanto et al., 2016). Di dalam CI ini terdapat beberapa macam kelas yang berbentuk library dan helper yang berfungsi untuk membantu pemrogram dalam mengembangkan aplikasinya.

\section{MySQL}

MySQL merupakan database yang paling digemari dikalangan Programmer Web, dengan alasan bahwa program ini merupakan database yang sangat kuat dan cukup stabil untuk digunakan sebagai media penyimpanan data. Sebagai database server yang mampu untuk memanajemen database yang baik, MySQL terhitung merupakan database yang paling digemari dan paling banyak digunakan di banding database lainnya (Nugroho, 2005).

\section{Extreme Programming}

Extreme Programming (XP) adalah metode pengembangan perangkat lunak yang ringan dan termasuk salah satu agile methods yang dipelopori oleh Kent Beck, Ron Jeffries, dan Ward Cunningham. XP merupakan agile methods yang paling banyak digunakan dan menjadi sebuah pendekatan yang sangat terkenal. Sasaran $X P$ adalah tim yang dibentuk berukuran antara kecil sampai medium saja, tidak perlu menggunakan sebuah tim yang besar. Hal ini dimaksudkan untuk menghadapi requirements yang tidak jelas maupun terjadinya perubahan-perubahan requirements yang sangat cepat (Pressman dan Mxim, 2015).

\section{Unified Modelling Language (UML)}

UML merupakan bahasa visual untuk pemodelan dan komunikasi mengenai sebuah sistem dengan menggunakan diagram dan teks-teks pendukung. UML hanya berfungsi untuk melakukan pemodelan. Jadi penggunaan UML tidak terbatas pada metodologi tertentu, meskipun pada kenyataannya UML paling banyak digunakan pada metodologi berorientasi objek (Sukamto dan Shalahuddin, 2016).

\section{Blackbox Testing}

Blackbox testing dilakukan tanpa pengetahuan detail struktur internal dari sistem atau komponen yang dites. Juga disebut sebagai behavioral testing, specificationbased testing input/output testing atau functional testing. Dengan adanya blackbox testing, perekayasa software dapat menggunakan sekumpulan kondisi masukan yang dapat secara penuh memeriksa keseluruhan kebutuhan fungsional pada suatu program (Mustaqbal, Firdaus dan Rahmadi, 2015).

\section{Pembahasan}

\section{A. Use Case Diagram}

Usecase diagram dapat dilihat pada gambar 1 berikut: Pada aplikasi perizinan praktik tenaga kesehatan terdapat tiga aktor yang dapat berinteraksi untuk dapat menggunakan fungsi-fungsi didalamnya. Usecase diagram dilihat pada gambar dibawah.

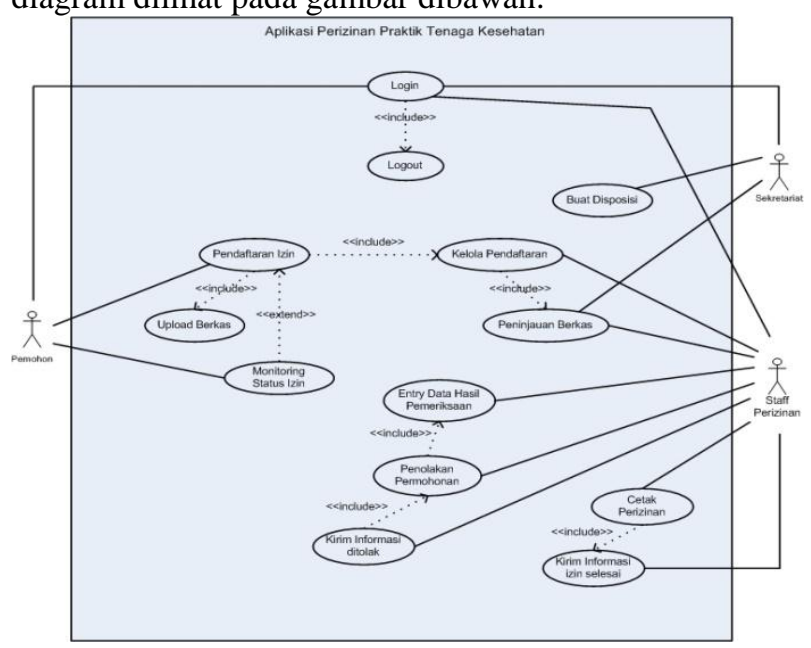

Gambar 1. Use Case Diagram 


\section{B. Activity Diagram}

Diagram ini menjelaskan bagaimana aktifitas yang dilakukan dari para aktor yang terlibat dalam sistem yang berjalan (Mei Lisda Sari, 2012). Activity diagram dilihat pada gambar 2 dibawah.

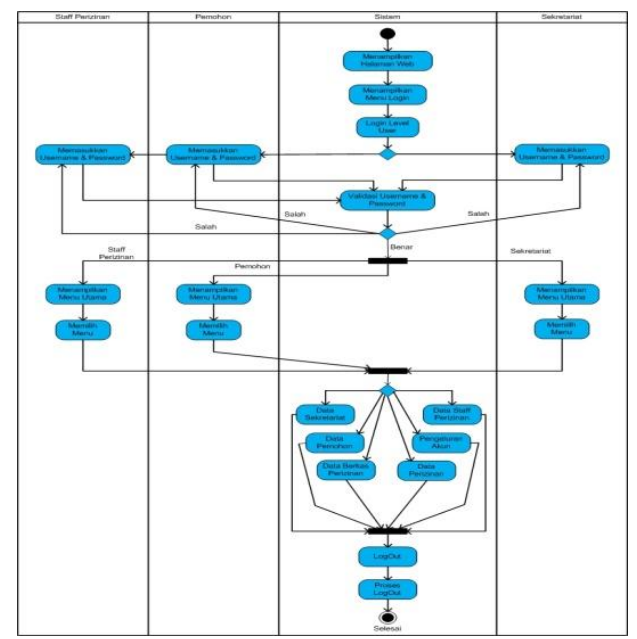

Gambar 2. Activity Diagram

\section{Class Diagram}

Class diagram dapat dilihat pada gambar 3 berikut:

Class diagram merupakan suatu diagram yang memperlihatkan atau menampilkan struktur dari sebuah sistem, sistem tersebut akan menampilkan sistem class, atribut dan hubungan antara kelas ketika suatu sistem telah selesai membuat diagram (Subhiyakto et al., 2017). Class diagram dilihat pada gambar 3 dibawah.

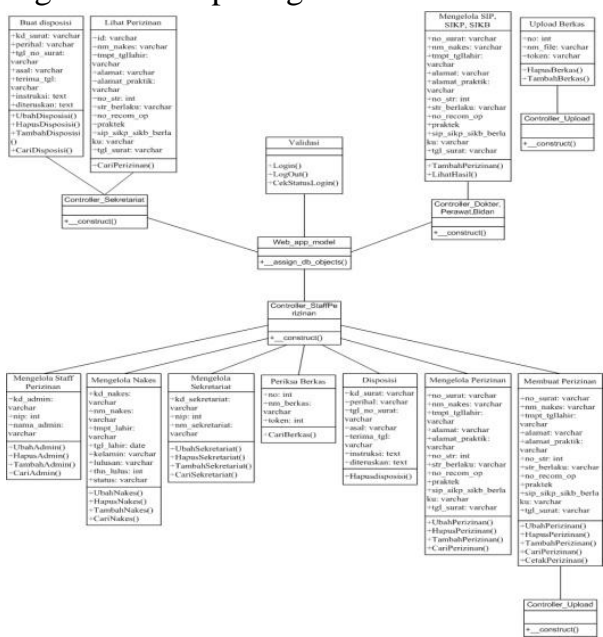

Gambar 3. Class Diagram

\section{Implementasi Sistem}

\section{Login User}

Form login Merupakan halaman yang pertama kali muncul ketika aplikasi web dibuka, yang dapat digunakan untuk mengakses halaman web, selain yang tidak memiliki hak akses seperti username dan password tidak akan dapat masuk ke sistem tersebut dan tidak dapat mengaksesnya, yang hanya dapat mengakses sistem ini adalah admin, tenaga kesehatan dan sekretariat. Adapun tampilan form login dapat dilihat pada gambar 4:

\section{APTK Online}

\section{Username dan Password Anda:}

\section{Username}

.

Password

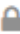

\section{a Login}

\section{E. Halaman Utama Staff Perizinan}

Form halaman utama staff perizinan / admin merupakan halaman yang muncul setelah melakukan login admin. Form ini berisikan data tenaga kesehatan, sekretariat, SIP, SIKP dan SIKB, disposisi, periksa berkas, buat perizinan SIP, SIKP, SIKB dan pengaturan akun, halaman dapat dilihat pada gambar 5 sebagai berikut.

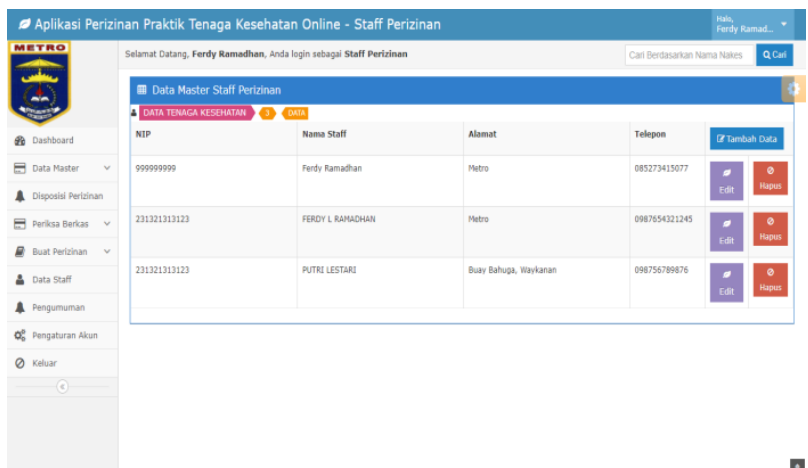

Gambar 5. Halaman Utama Staff Perizinan

\section{F. Form Data Tenaga Kesehatan}

Form data tenaga kesehatan merupakan halaman yang tampil ketika admin memilih menu data master kemudian memilih submenu tenaga kesehatan, sistem akan menampilkan daftar nama-nama tenaga kesehatan yang ada di dalam sistem. Dalam form ini admin dapat melakukan tambah data, pencarian, hapus maupun merubah data tenaga kesehatan. Adapun tampilan form data tenaga kesehatan dapat dilihat pada gambar 6: 


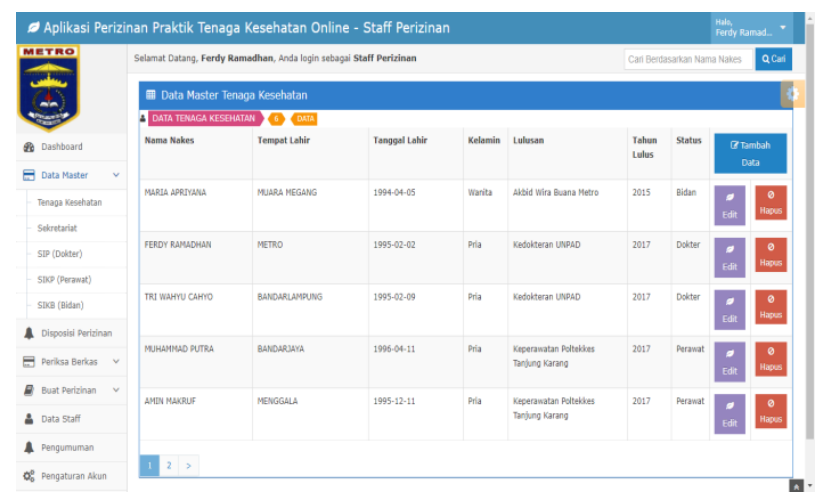

Gambar 6. Form Data Tenaga Kesehatan

\section{G. Form Data Sekretariat}

Form data sekretariat merupakan halaman yang tampil ketika admin memilih menu data master kemudian memilih submenu sekretariat, sistem akan menampilkan daftar nama-nama sekretariat yang ada di dalam sistem. Dalam form ini admin dapat melakukan tambah data, pencarian, hapus maupun merubah data sekretariat. Adapun tampilan form data sekretariat dapat dilihat pada gambar 7:

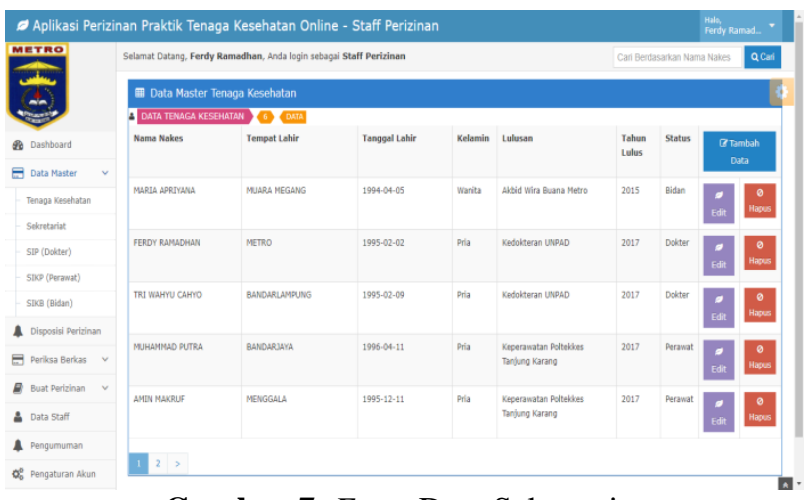

Gambar 7. Form Data Sekretariat

\section{H. Form Data Perizinan SIP}

Form data perizinan sip merupakan halaman yang tampil ketika admin memilih menu buat perizinan kemudian memilih submenu sip, sistem akan menampilkan data perizinan sip yang ada di dalam sistem. Dalam form ini admin dapat melakukan tambah data, pencarian, hapus maupun merubah data perizinan sip. Adapun tampilan form data perizinan sip dapat dilihat pada gambar 8 :

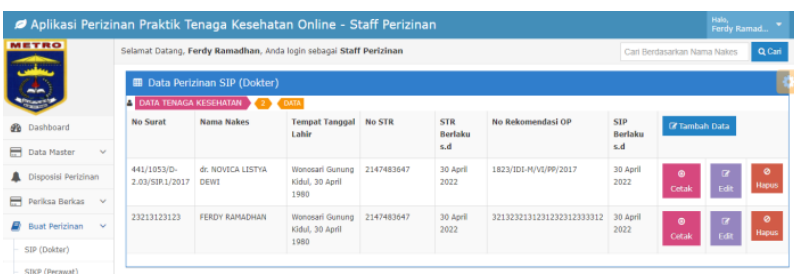

Gambar 8. Form Data Perizinan SIP

\section{Form Cetak Perizinan SIP}

Form cetak data perizinan sip merupakan halaman yang tampil ketika admin memilih submenu perizinan sip, kemudian memilih tombol cetak, kemudian form cetak data perizinan sip akan tampil. Form ini berfungsi untuk menampilkan data perizinan sip dalam bentuk format pdf yang bisa disimpan dengan cara download atau save as Adapun tampilan form cetak perizinan sip dapat dilihat pada gambar 9:
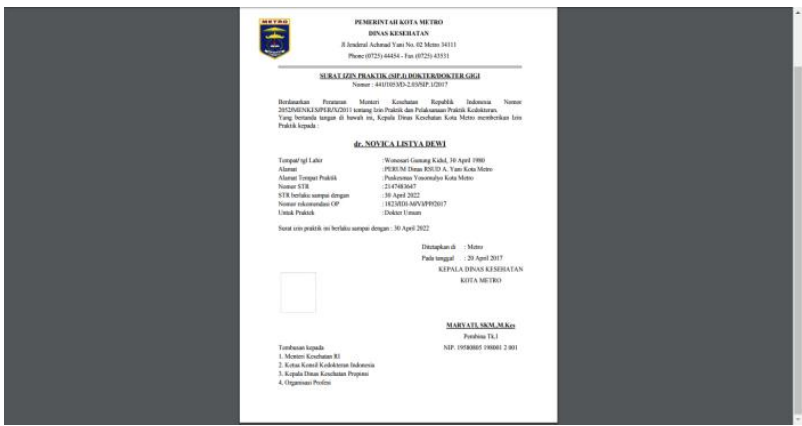

Gambar 9. Form Cetak Perizinan SIP

\section{J. Form Data Staff Perizinan (Admin)}

Form data staff perizinan merupakan halaman yang tampil ketika admin memilih menu data admin, sistem akan menampilkan data staff yang ada di dalam sistem. Dalam form ini staff dapat melakukan tambah data, pencarian, hapus maupun merubah data admin. Adapun tampilan form data staff perizinan dapat dilihat pada gambar 10:

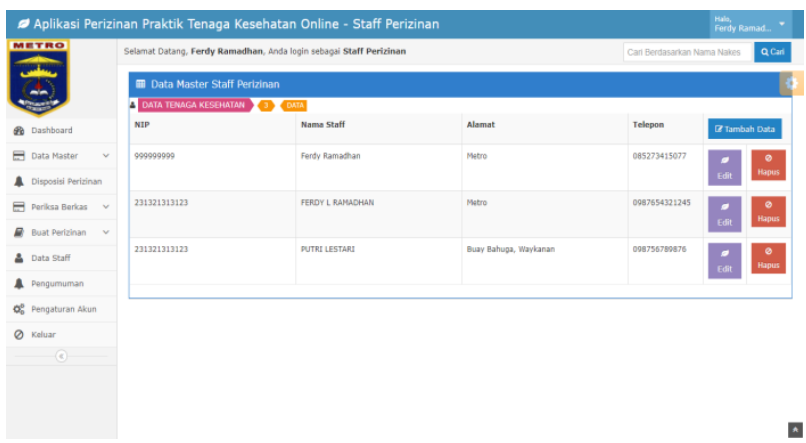

Gambar 10. Form Data Staff Perizinan

\section{K. Form Pengumuman}

Form pengumuman merupakan halaman yang tampil ketika admin memilih menu pengumuman, sistem akan menampilkan data pengumuman yang ada di dalam sistem. Dalam form ini admin dapat melakukan tambah data, pencarian, hapus maupun merubah data pengumuman. Adapun tampilan form pengumuman dapat dilihat pada gambar 11: 


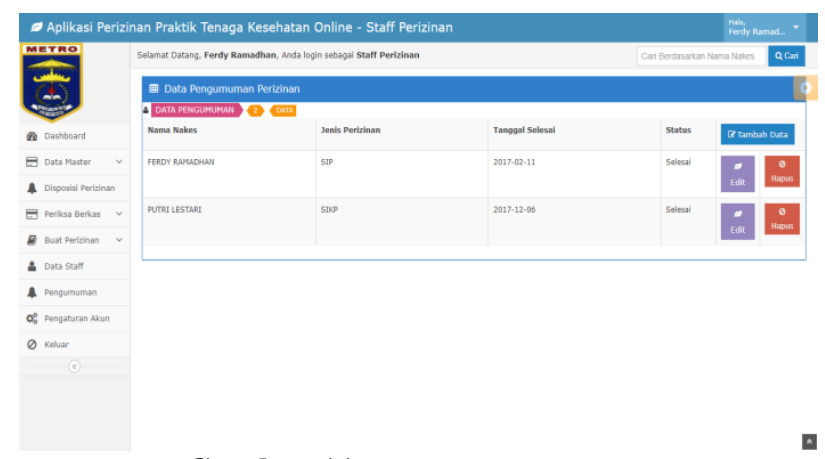

Gambar 11. Form Pengumuman

\section{Form Pengaturan Akun}

Form pengaturan akun merupakan halaman yang tampil ketika admin memilih menu pengaturan akun. Form ini berfungsi untuk mengubah password admin. Adapun tampilan form pengaturaan akun dapat dilihat pada gambar 12:

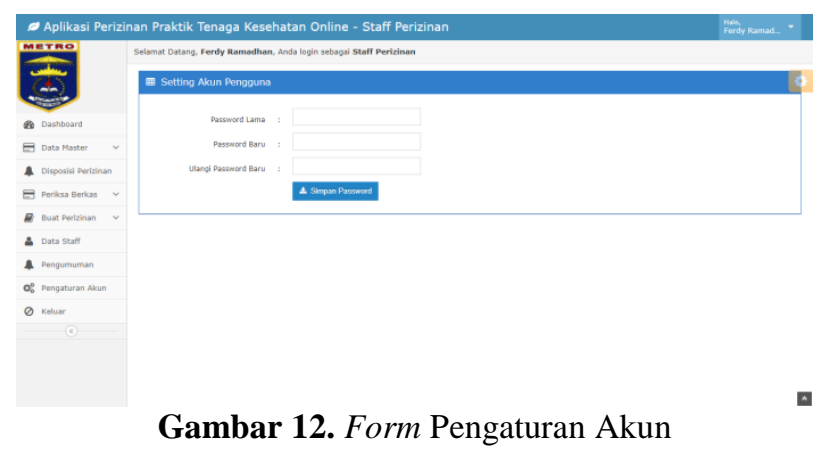

\section{Form Input Perizinan Dokter}

Form perizinan dokter merupakan halaman yang tampil ketika dokter memilih menu perizinan dokter. Form ini berfungsi untuk menginputkan data perizinan dokter (SIP) mulai dari kode nakes, nama tenaga kesehatan, tempat lahir, tanggal lahir, jenis kelamin, nomor str, nomor rekomendasi op, alamat rumah, telepon, nama sarana kesehatan 1, alamat sarana kesehatan 1, nama sarana kesehatan 2, alamat sarana kesehatan 2, nama sarana kesehatan 3, alamat sarana kesehatan 3. Adapun tampilan form input perizinan dokter dapat dilihat pada gambar 13:

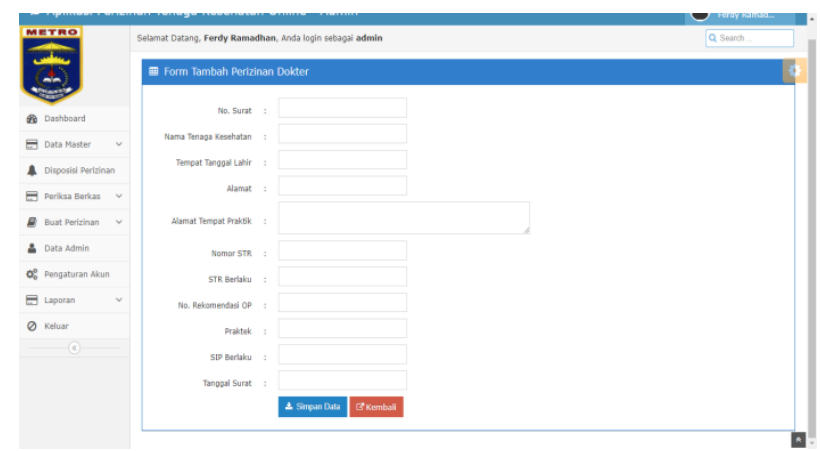

Gambar 13. Form Input Perizinan Dokter

\section{N. Form Upload Berkas SIP}

Form upload berkas sip merupakan halaman yang tampil ketika dokter memilih menu upload berkas. Form ini berfungsi untuk mengupload file gambar dalam bentuk scan sebagai syarat dalam memproses perizinan. Adapun tampilan form upload berkas SIP dapat dilihat pada gambar 14:

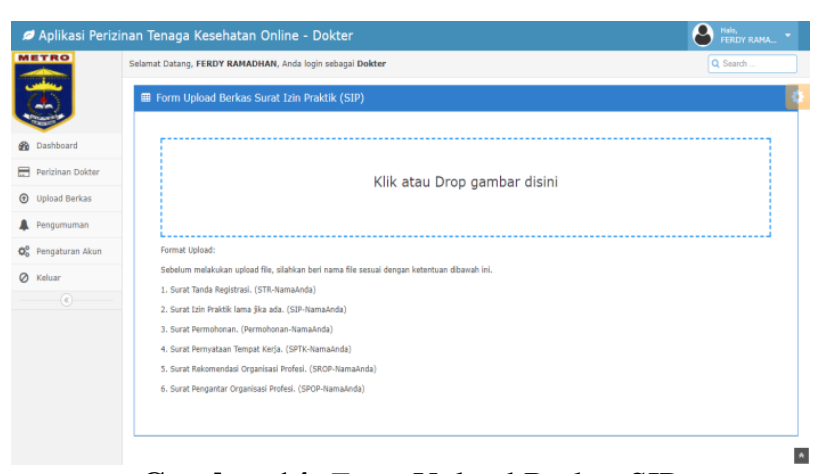

Gambar 14. Form Upload Berkas SIP

\section{O. Form Data Disposisi}

Form data disposisi merupakan halaman yang tampil ketika admin memilih menu disposisi perizinan, sistem akan menampilkan data disposisi yang ada di dalam sistem. Dalam form ini sekretariat dapat melakukan tambah data, mengubah data, dan hapus data disposisi. Adapun tampilan form data disposisi dapat dilihat pada gambar 15:

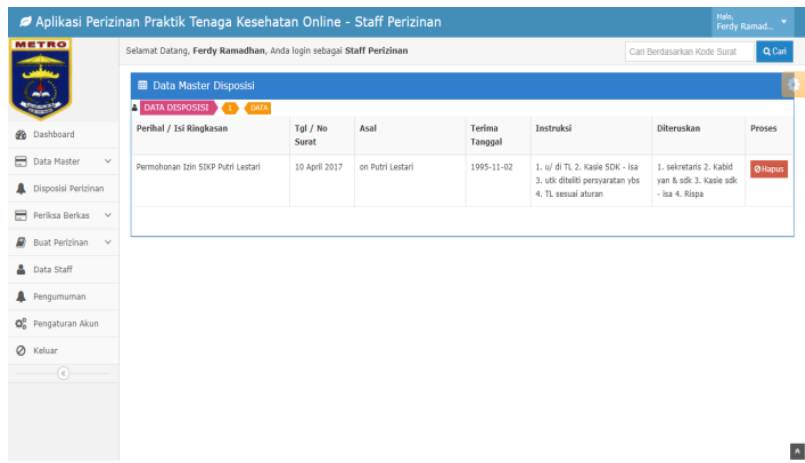

Gambar 15. Form Data Disposisi

\section{Kesimpulan}

\subsection{Kesimpulan}

1. Aplikasi dapat digunakan oleh Staff Perizinan, Sekretariat, dan Tenaga Kesehatan untuk mempermudah dan mempercepat proses perizinan kerja tenaga kesehatan pada lingkungan Pemerintah Kota Metro Provinsi Lampung.

2. Hasil pengujian blackbox aplikasi perizinan kerja tenaga kesehatan yaitu sebagai berikut:

a) Hasil pengujian staff perizinan / admin oleh 4 (empat) orang staff perizinan Dinas Kesehatan Kota Metro menunjukkan bahwa aplikasi dapat melakukan semua fungsinya dengan benar sehingga kualitas perangkat lunak $100 \%$ valid. 
b) Hasil pengujian sekretariat oleh 2 (dua) orang sekretariat Dinas Kesehatan Kota Metro menunjukkan bahwa aplikasi dapat melakukan semua fungsinya dengan benar sehingga kualitas perangkat lunak 100\% valid.

c) Hasil pengujian pemohon / tenaga kesehatan dokter, perawat, dan bidan yang diwakili oleh 4 (empat) orang staff perizinan Dinas Kesehatan Kota Metro menunjukkan bahwa aplikasi dapat melakukan semua fungsinya dengan benar sehingga kualitas perangkat lunak $100 \%$ valid.

\section{Ucapan Terimakasih}

Terimakasih untuk Dinas Kesehatan Kota Metro Provinsi Lampung atas informasi dan data yang diberikan hingga penelitian ini selesai dengan baik.

\section{Daftar Pustaka}

Hidayah, N. A., Utami, M. C. dan Suhendar, A. T. (2015) "Pelayanan Haji Dan Umroh Berbasis Web ( Studi Kasus: Kbih AlKarimiyah Depok )," Studia Informatika: Jurnal Sistem Informasi, 8(2), hal. 1-12.

Mei Lisda Sari (2012) Apa itu Use Case, Activity Diagram, dan Sequence Diagram? | Talking to myself, 2012.

Misnaniarti (2010) "ASPEK PENTING PENGEMBANGAN DAN PEMBERDAYAAN SUMBER DAYA MANUSIA (SDM) KESEHATAN DI ERA DESENTRALISASI," Jurnal Ilmu Kesehatan Masyarakat, 1(01), hal. 12-19. Tersedia pada: http://download.portalgaruda.org/article.php?article=250017\&val= 6663\&title=DEVELOPMENT AND EMPOWERMENT OF HEALTH HUMAN RESOURCES THE IMPORTANT ASPECT IN DECENTRALIZATION.

Mustaqbal, M. S., Firdaus, R. F. dan Rahmadi, H. (2015) "Pengujian Aplikasi Menggunakan Black Box Testing Boundary Value Analysis," Jurnal Ilmiah Teknologi Informasi Terapan, I(3), hal. 31-36.

Nugroho, B. (2005) Database Relasional dengan MySQL, Andi: Yogyakarta.

Pressman, R. S. dan Mxim, B. R. (2015) Software engineering, ACM SIGSOFT Software Engineering Notes. doi: 10.1145/1226816.1226822.

Sopacua, E. dan Budijanto, D. (2007) "Opsi-opsi Kebijakan untuk Pelatihan Sumber Daya Manusia Kesehatan: Pembelajaran dari Penelitian Pola Peningkatan Kompetensi Sumber Daya Manusia dalam Otonomi Daerah Bidang Kesehatan," Jurnal Manajemen Pelayanan Kesehatan, 10(04), hal. 173-180.

Subhiyakto, E. R. ; et al. (2017) "Rancang bangun sistem informasi pengarsipan data pasien klinik cemara," Techno.com, 16(1), hal. 25-34.

Sukamto, R. A. dan Shalahuddin, M. (2016) "Rekayasa Perangkat Lunak," UML (Unified Modeling Language), 4, hal. 133-171.

Yudhanto, Y. et al. (2016) "PERANCANGAN DAN PEMBUATAN APLIKASI D3 TEKNIK INFORMATIKA UNS BERBASIS WEB DAN ANDROID," Indonesian Journal of Applied Informatics, 1(1). 